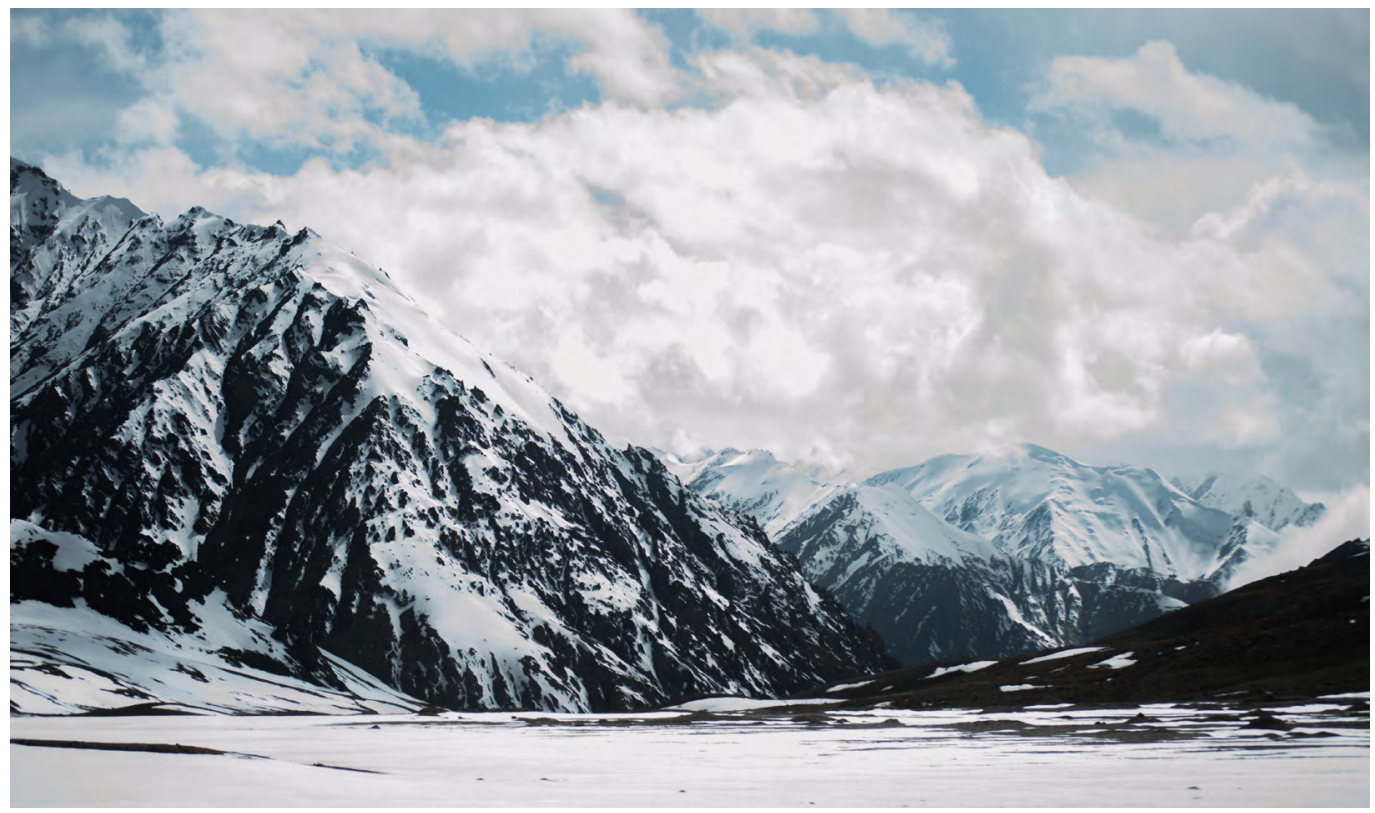

\title{
China : Xinjiang :: India : Kashmir
}

The Karakorum, at the border between Southern Xinjiang and Kashmir PC: Tahakhan021, Wikimedia Commons.

\section{Nitasha KAUL}

This essay examines the parallels between the two 'rising powers' China and India when it comes to the treatment of the Othered populations, with a specific focus on how this has been experienced by the Muslim majority populations of Xinjiang and Kashmir. It highlights the way in which colonialism has come be understood as a moral wound of the colonised that manipulates imaginaries of pride and futurity by these projects and their leaders.

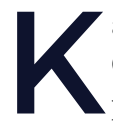
ashmir and Xinjiang share a border. Or, more precisely, the erstwhile princely state of Kashmir that is now divided between India, Pakistan, and China (and officially known as Jammu and Kashmir and Ladakh; Azad Kashmir and Gilgit Baltistan; Aksai Chin, respectively) shares a border with eastern Turkestan and Tibetcurrently officially called Xinjiang and Xizang. In addition to this geographic proximity, Kashmir and Xinjiang are marked by a complex patchwork of ethnic and religious identities, and have borne the weight of contested sovereignty claims throughout most of the modern era.

The specific regions with Muslim-majority populations in Kashmir and Xinjiangthe Kashmiri Muslims are concentrated predominantly in the Kashmir Valley, and 
the Uyghur Muslims in East Turkestan-have witnessed a particular form of political power as exercised by the two rising behemoths India and China. This has included systematic human rights violations in the name of curbing separatism and terrorism. The political relationships of these regions with the Indian and Chinese states reveal important similarities and differences. The similarities are occasioned by the fact that these ethnonationally different Muslim-majority areas have become the focus of assimilation into the evolving Hindu majoritarian nationalism in India and Han majoritarian nationalism in China. Both India and China claim these territories as integral parts of their nationstates.

While Indian Muslims and Hui Muslims in China do not have any overwhelming affinity with the ethnically different Kashmiri and Uyghur Muslim struggles, India and China have still sought to suppress the religious and cultural identities of these peoples by framing them solely as radicalised Muslims; examples include changes to architecture and restricting access to places of worship. This is in line with a broader stigmatisation of their Islamic and ethnic identities as being always already suspect and in need of securitisation. The broader global and regional variants of Islamophobia are an important way to secure justifications for why these people are marginalised (Brophy 2019). The rationale-for putting them into reeducation camps in China, revoking their autonomy without consent in India, imprisoning activists, denying access to the Internet and communications, altering the demography of the region, and prohibiting any meaningful Kashmiri or Uyghur dissent in both the Indian and the Chinese cases-is that all this is being done in order to stamp out terrorism, and to modernise and 'develop' these populations. What this rhetoric has translated into is at best a 'violent paternalism' (Byler 2018), and at worst a prolonged collective punishment of these populations in their own homelands (Anand 2012 and 2019).
Although the purported attempts at modernisation and development have proceeded along somewhat different lines in the two contexts, there is a distinct possibility that in the final instance what China is doing today in Xinjiang may be predictive of the Indian trajectory in Kashmir. In this essay, I will provide a background to the Kashmir region and an overview of some of the recent changes, and then theorise why India and China are able to continue acting in this manner towards those in Kashmir and Xinjiang. I conclude by calling for a greater transregional understanding of these strategies and more solidarity across different contexts.

\section{Kashmir: The Background}

Over the past two centuries, Kashmiris as a people have had their identities constructed out of prolonged experiences of multiple colonisations-from the Mughal to the Sikh empires, Dogra direct rule, British suzerainty, and contemporary Indian and Pakistani control and administrative claims. These rules were legitimised through a mix of treaty provisions, elite bargains, and securitisations (Kaul 2011). While the precise boundaries and jurisdictions of the erstwhile princely state of Jammu and Kashmir shifted over time, the area nevertheless amalgamated a range of different regional, religious, and ethnic populationsall of which are, with different degrees of volition, able to trace one irreducible element of their identity as Kashmiri, even if, in some cases, this simply means being historically bracketed into the territorial bargains of the former state. The three provinces of the state-Jammu (with several districts), Kashmir (with districts in the Kashmir Valley), and the Frontier Districts (Ladakh, Gilgit, Baltistan, and Poonch/Muzaffarabad)-were carved up following the Partition in South Asia, when the independence of British India led to the 


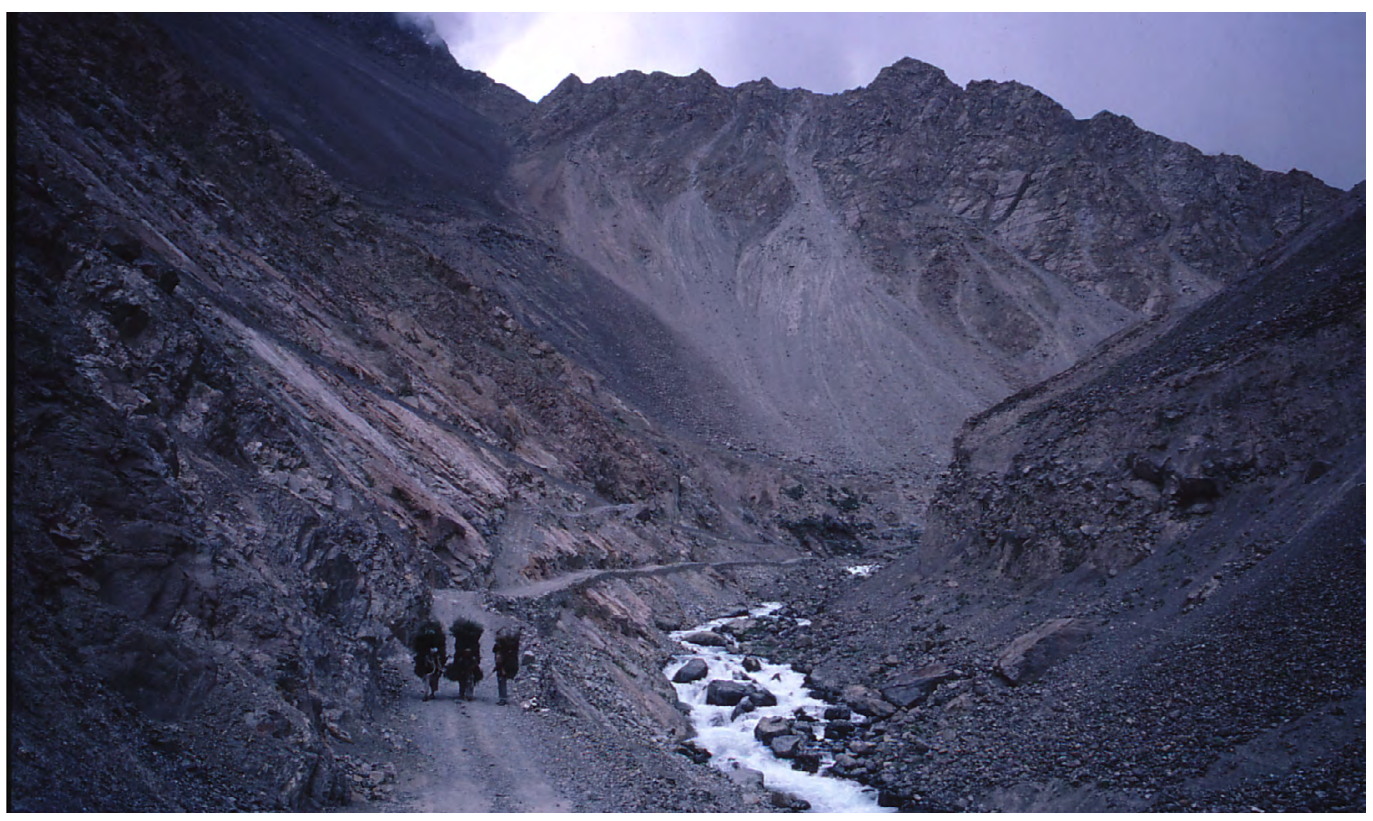

Mountain route in Kashmir, 1983 PC: Ole Holbech.

creation of India and Pakistan. Since their very inception, these two nation-states have been marked internally by the competing and anxious postcolonial nationalisms in their turbulent political dynamics, and externally by the global scenario of the Cold War and its fallout, the ascendant neoliberal consensus, and the protean War on Terror.

Against this setting, Kashmir has remained an unresolved existential issue for India and Pakistan, whose rivalry has played out in a combination of military force, legal impunities, preferred state-centric media framings, cloakand-dagger politics, and strategic alliances on subsets of economic and political issues with powerful, though problematic, entities (such as China, the United States, and the United Kingdom). Only rarely has this confrontation been conducted through artful diplomacy, let alone by showing any human concern for the Kashmiris affected. By the start of the twentyfirst century, with the coming into being of a new global Other via post-9/11 Islamophobia, the rise of Hindu nationalism in India, and following the multiple wars between the two countries, the dominant narrative of the 'Kashmir problem' came to be centred on the Kashmir Valley and its Muslim-majority population. This was in no small measure due to the communalisation of the political dispute because of a number of factors that include: a) the nationalist Indian position being unable to distinguish between a proxy Pakistan-backed armed insurgency and an anti-Indian uprising with popular support fuelled by decades of accumulated resentment; b) Pakistan's twonation theory, which sees Hindus and Muslims as distinct, irreconcilable nations; c) episodes of anti-minority (anti-Kashmiri Pandit) violence carried out by Islamic militants, and the forced exodus of Kashmiri Pandits under threat of violence and with bafflingly little promised protection to stay put in their homeland from the Indian state; and d) the overwhelming and multidimensional violence directed at Kashmiri Muslims, combatants 


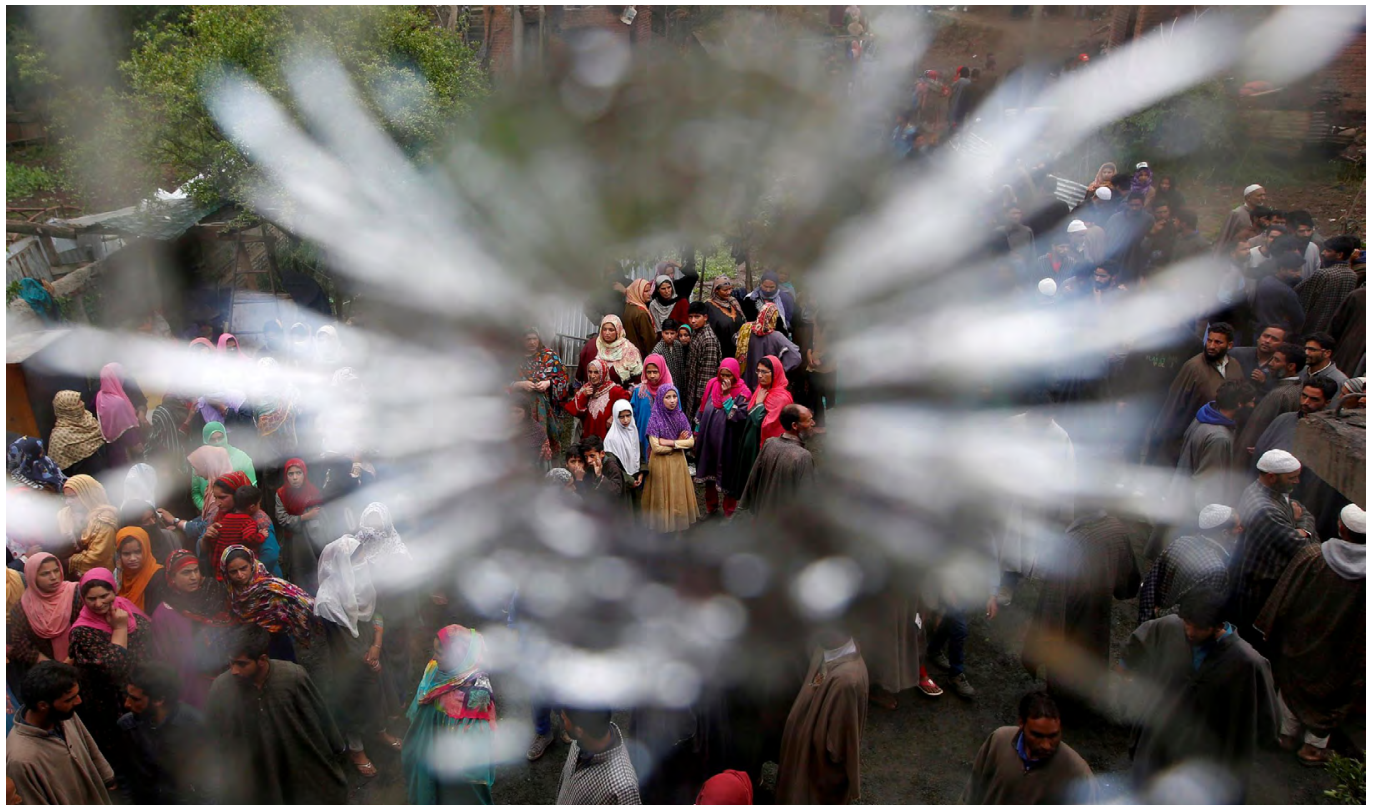

People protest against India in Kashmir,

September 2018. PC: Ubaidsardar, Wikipedia.

and civilians both, by Indian forces, which over the years have killed tens of thousands of Kashmiris, and left thousands victimised through enforced disappearances, torture, mass killings, and mass rapes-all of which has been well documented by human rights organisations.

In the past 10 years, newer chasms have opened up between the global, the national, the macropolitical, and the micropolitical when it comes to the different facets of Kashmiri identity, human rights, and political aspirations in relation to India and Pakistan. At a global level, the prolonged recession in the West and an aggressively marketed discourse of the 'rising powers' have meant the prioritisation of semantics over substance when it comes to India's democratic credentials. This has also involved an alternating mix of threat and awe regarding China's expanding economic and large-scale infrastructural connectivities through the Belt and Road Initiative, including the China-Pakistan Economic Corridor. In this scenario, human rights concerns-whether in Kashmir, Tibet, Xinjiang, Balochistan, or elsewhere-that used to be inserted as a staple into foreign policymaking in the West, and were already suffering from substantial critiques of selectivity and hypocrisy, finally fell prey to the rise of powerful and electorally legitimated right-wing leaders in the West, who quite literally mean only business, largely for themselves and their cronies. At the national level in India, the spectacular consolidation of the dream Hindutva project of the Rashtriya Swayamsevak Sangh (RSS), a powerful right-wing nationwide paramilitary organisation, and the rise of the Bharatiya Janata Party (BJP) led by Narendra Modi, with its particular governmentality of 'postcolonial neoliberal nationalism'-which co-constructs ideas of the economy and nation (Kaul 2019a)have sought to create India, first and foremost, as a Hindu nation akin to a Muslim Pakistan. In these political scripts, the Kashmiris struggling for human rights and/or political 
self-determination have been essentialised as separatist Muslims who need to be subdued by any means possible, because they are not political human beings, but problematic Muslims qua Muslims.

In all of this, the issue of Kashmiri Pandits has been weaponised like never before to justify the Hindutva-motivated Indian actions in Kashmir; the Hindutva idea of India sees only Hindu Kashmiri Pandits as 'true' Kashmiris, just as it sees Hindu Brahman Indians as the ideal subjects of the 'pure' Hindu nation. At the macropolitical level, the distance between the imaginaries and mutual cognition of aspirations in the different regions-Jammu, Kashmir, and Ladakh-has increased significantly as a result of policies that consciously foster selective connectivities and relationalities, and cultivate rival leaderships. At the micropolitical level, the accumulated resentments of the Kashmiri people, especially of the post-1990 generation, have become multilayered metamorphic rocks of grievances, symbolically like the rocks that are pelted by masked youths at the soldiers who are seen as the visible human symbols of an unjust and occupying colonial state.

\section{Kashmir Today}

In 2020, as the world reeled under the impact of the coronavirus pandemic and different countries staggered through various stages of prolonged lockdowns, the people in Kashmir experienced the fallout of a combination of poor health infrastructure and a fractal version of lockdowns within lockdowns as many of the restrictions on telephony and telecommunications put in place in August 2019 had not yet been fully lifted. This was a direct consequence of the events resembling a 'constitutional coup' that took place in the summer of 2019. On 5 August 2019, the Indian government stripped Jammu and Kashmir (J\&K) of its constitutionally guaranteed autonomy by revoking Article 370 of the Constitution, which gave J\&K autonomy over everything except defence, telecommunications, and foreign affairs. In addition to ending autonomy, the statehood of $\mathrm{J} \& \mathrm{~K}$ was also taken away and it was split into two union territories: Jammu and Kashmir as one, and Ladakh as the other.

This occurred overnight, without the consent of the state legislature or the people of the region. To thwart any dissent, all landline and mobile telephony and Internet communications were shut down, curfew-like conditions were imposed, political and civil society leaders from across the spectrum were preventively arrested, no-fly lists were created, and large numbers of people, including children, were imprisoned, sometimes outside the state (Kaul 2019b and 2019c). As the flag of $\mathrm{J} \& \mathrm{~K}$ was removed from buildings and police forces were brought under the control of the Union Home Ministry based in New Delhi, Indian opposition leaders were prevented from visiting the region, and a delegation of far-right European parliamentarians was taken on a tour and photographed against scenic backgrounds in the deserted landscape. Foreign media, critical Indian media, and a US senator were refused access; only state-approved media were permitted to function at media facilitation centres where the chosen few could access the Internet for 15 minutes at a time. This Internet shutdown continued for months, making it the longest ever Internet blockade in any democracy. As of writing, in late autumn 2020, 4G Internet services have still not been restored in spite of the coronavirus pandemic.

Underlying these developments were clear intentions of a transition to full-throated settler-colonialism. As these events were set in motion in 2019, ruling-party politicians in India celebrated the change as something that would allow them to marry 'fair-skinned Kashmiri women'. In the manner of a typical Orientalist fantasy, Kashmir has always been exoticised and feminised in the Indian imagination (Kaul 2018). The Muslim men of Kashmir especially are seen as the cruel Other, latent terrorists who are always already suspect in their politics. So far, 2020 in Kashmir has seen 
further amendments to the law and policies that confirm these settler-colonial intentions. The law was changed so that non-citizens of former J\&K can now receive fast-tracked domicile status based on residency there. In the middle of the coronavirus pandemic, in July 2020, masses of Indian workers were brought into Kashmir to work in brick kilns. Also in the same month, the law was changed to allow the designation of any area as strategic, permitting permanent constructions to be made there for the use of the armed forces. At the same time, housing and urban development policy has been changed to allow the building of hundreds of thousands of different dwellings, ranging from slum redevelopment to integrated townships, through public-private partnerships, for which contracts will be awarded. Kashmiris fear that all these developments taken together will result in overwhelming demographic change the mass settlement of outsiders. That this is not mere doom-mongering is supported by the fact that, in November 2019, the Indian ConsulGeneral in New York was filmed at an event as he comparing the return of Kashmir's Hindu minority to Israeli settlements-in his words: 'If the Israeli people can do it, we can also do it' (Express News Service 2019).

\section{India's Camps}

China plays a complex role in the Indian public imagination and politics-often perceived as a very different Other; India is projected as democratic and China as Communist authoritarian. Yet, China is also seen as worthy of emulation for its economic and infrastructure growth, and in the ability of its leaders to evading the problems of democratic dissent. India's Prime Minister Modi is portrayed as a 'strong' leader, is presented to his masses of followers, someone who can keep democratic noise under control and succeed in the way that China has done.
While sections of the Indian media wonder why China hates its Muslim Uyghur minority, they seem comfortable ignoring the everincreasing and systematic Islamophobic violence in India itself, which is made worse by police inaction or brutality, lack of prompt official condemnation, and inexcusable judicial delays or quietude. It is possible for Indian TV anchors to highlight the plight of the Uyghurs, the lack of religious freedom, and the construction of concentration camps in China; however, the plight of Kashmiri Muslims, the persecution of Indian Muslims, and the construction of detention camps in India receive barely any mainstream attention.

In spite of widespread protests, the recent, controversial Citizenship Amendment Act (CAA) succeeded in creating a religious basis for access to Indian citizenship, but Islam is excluded. Furthermore, the Indian government is planning to establish a National Register of Citizens, and attempts at citizenship verification in certain areas of the country have resulted in the creation of millions of stateless people, often from among those who are already socioeconomically marginalised (for instance, 1.9 million people in Assam, which is 6 percent of the state's population; see Rahim 2019). Much to the chagrin of organisations such as the right-wing paramilitary RSSthe ideological parent of the ruling BJP-a large number of Hindus are among the newly stateless people (Rahim 2019). However, while the new CAA allows these Hindus to find a route back into Indian citizenship, their Muslims counterparts are purposely left in a limbo.

An anti-immigrant and Islamophobic agenda is a key staple of the Modi-led BJP, which has been in power since 2014 and has made no secret of endorsing this agenda by refusing to condemn anti-minority violence and indulging in outright hate-speech against 'Muslims' and 'foreigners'-both of whom are amalgamated into a composite figure by denying the centuries of Mughal history. In 
2014, India's central authorities asked all the provinces to set up at least one detention camp to separate criminals from illegal immigrants or foreigners awaiting deportation after completing their sentences due to the impossibility of confirming their nationality (Kalita 2019). Construction has since begun on a number of detention camps throughout the country, with the process gathering pace over the past couple of years (Sen and Singaravelu 2020; Uniyal 2020). While Modi denied the existence of any such camps, lawmakers have accepted that these exist (IANS 2019). Also, contrary to the claims by the government that the inmates are housed with dignity and not deprived of basic facilities, there have been reports of numerous deaths in the camps in Assam (Krishnan 2020). The resources needed to set up and run these detention camps make them likely candidates to form a blooming 'sunrise industry' (Balakrishnan 2019).

In the context of Kashmir, a different kind of camp is being proposed. In January 2020, General Bipin Rawat, Chief of India's Defence Staff, suggested that Kashmiris could be taken away to 'deradicalisation camps' (Gettleman and Schultz 2020). For many Kashmiris, this echoes the camps in Xinjiang and portends a similar fate awaiting them. The military did not clarify these remarks, but after what was done to Kashmir in the constitutional coup of August 2019, no nightmare is beyond imagination since democratic checks are fast disappearing in the face of a craven judiciary, censored and self-censoring media, targeted attacks on civil society spokespeople and activists, and a wide-ranging Hindu-majoritarian overhaul of the country's historical, social, cultural, and political identities. A hostile attitude towards the Kashmiri population is nothing new. In 2017, the same general-who at that time was army chief-applauded the use of a Kashmiri civilian tied to the front of a military vehicle as a human shield, calling it an 'innovation'; he also expressed the wish that the Kashmiri people would fire weapons instead of throwing stones so that he could do what he wanted with them (Safi 2017).

\section{The Moral Wound of Colonialism and the Postcolonial Error}

Mass internment camps as sites for the deprivation of people's rights and liberties have an inextricable relationship with colonial history and, over the past two centuries, they have been used by a large number of countries across the globe. In fact, governments like those of India and China are only too keen to point to this history of colonial atrocities carried out by Euro-American nations. Added to this is the hypocrisy and selectivity with which 'the West' has pursued its human rights agenda during the period of the Cold War, how it has carried out 'humanitarian intervention' in its aftermath through the invasions of Iraq and Afghanistan, and suppressed the rights and liberties of its own citizens under the guise of the War on Terror. Taken together, this adds up to a convenient nativist discourse that officials in countries like China and India use to justify their own behaviour in Xinjiang, Kashmir, and elsewhere.

When we think about how large and diverse countries such as China and India are able to create consent among their own majority populations, and globally, to support their actions in Xinjiang and Kashmir, we find two important explanatory variables: media censorship and nation-state-centric media coverage of these issues; and how the ignorance and indifference of the wider world to the fate of these oppressed Muslim populations are tied to access to Indian and Chinese markets and global commodity value chains. However, there is a third, equally important way in which Indian and Chinese-and other non-Westernpopulations consent to the treatment of Kashmiri and Uyghur people. This relates to the West/non-West divide in the understanding of the history of human rights, and the role of colonial history in this. This third point is my focus here. 
It is important to analyse the role of colonial history in the present, and I theorise this through what I call the moral wound of colonialism. Let me explain. To begin with, notwithstanding their geographical proximity, or demographic similarity, or strategic treatment, there is a striking paucity of academic work looking at the Kashmir and Xinjiang cases side by side. Such an understanding is often hard to obtain because of the stable sense in which the signifier 'the West' is understood. In the inherited historiography that presents a perennial structuring of colonial power as between 'the haves' of the West and 'the have-nots' of the non-West, there is no place to perceive a colonial exercise of power by the non-West, unless it is only seen only as reflective of the divide-and-rule agenda of the West. This is a significant conceptual problem.

It is sustained by thinking that perceives colonialism as a 'moral wound' to the formerly colonised rather than to the colonisers. To have been colonised in the past is understood as a matter of moral shame and humiliation for the colonised, but there is no dominant equivalent narrative of moral shame and humiliation for having been a coloniser nation. The idea that a state, interpreted as a political community, is justified in acting colonially over territory and peoples that it seeks to control largely goes unchallenged due to the way in which history is taught in teleological and triumphalist terms. Critical challenges to this rarely make it through to the mass media and wider public consciousness and, when they do, it is in the guise of token appreciation of a handful of secular, humanist, liberated, Western-educated, anti-colonial intellectuals. It is certainly the case that what is seen as humiliating is less the carrying out of brutal colonial oppression, and more the inability to have successfully resisted it. In this way, the glory of imperial colonial power is never sufficiently critiqued and the humiliated-yetvirtuous nativist sense of having been colonised is never critically understood either.
This discourse creates the perfect recipe for messianic leaders to manipulate imaginaries of time along the lines of pride and futurity, and promise the future as a return to a glorious past-either of putative precolonial purity in non-Western countries or of imperious and wide-ranging territorial control in Western countries. In each case, the fantasy is predicated on the idea of making a country great again. Manifest in this-what I call a postcolonial error (in both the formerly colonising and the formerly colonised countries)-is the latent potential for a double bind: the non-West can achieve glory along the colonial lines of the historical West by overcoming its past humiliation, but the non-West has a virtuous inability to be a coloniser because of having been previously colonised. Thus, at the same time, a non-Western country, humiliated through previous formal or informal colonisation, seeks to perform economic and political power in the way of the historical West, and yet is immune to the possibility of playing the role of coloniser in its own peripheries. This is effectively the essence of what the moral wound achieves in political terms in the contemporary era.

When India or China is presented as a 'rising power', this is precisely how 'power' is understood and what is meant by its 'rising'. There is, of course, no logical, historical, biological, or empirical reason to sustain the claim that formerly 'humiliated' or colonised non-Western countries are effectively immunised from acting as colonisers themselves. But attempts to highlight the colonial actions of non-Western countries like India and China are usually answered with the retort that these criticisms are just a regressive, Indophobic or Sinophobic, perhaps even racist, ploy to stop these powers from rising because they are not Western. One might further ask what precisely does being nonWestern mean in this context? What is the role of the signifier 'the West' in the idea of 'the non-West'? It certainly does not mean the absence of consumerism, capitalism, and allied infrastructures of conspicuous consumption or urbanisation. When the signifier 'West' is 
raised in this manner, it refers specifically to the question of liberties and rights and, most specifically, human rights.

This, in a single stroke, relinquishes the global legacy of the evolution of human rights-including anti-colonial struggles-to a purported triumphalist West. For the same reason, it also makes the possibility of human rights denial in the West invisible, while enabling the continuation of human rights denial in the non-West to go unchallenged. None of this means that there are not regressive Indophobic or Sinophobic, and even racist, voices in Western countries; in fact, many right-wing voices fit this description. However, this weaponisation of the category 'West' to deny rights in the non-West is fundamentally untenable because of the complexity of history, territory, and identity. Be it China's 'century of humiliation' (Callahan 2004) or the imaginary of the 'Golden Bird' that was India before British colonisation, the postcolonial error of conceptualising the moral wound of colonialism serves a very useful purpose in these countries. The Chinese challenge to global human rights discourse is well recognised (Chen 2019). India is on the same path, with the Indian Home Minister recently referring to the inapplicability of 'Western human rights' in India as the country would have its own expanded human rights linked to Indian values (The Wire 2019). Within this framing, the political aspirations, identities, and rights of minority populations in 'restive' regions cannot be framed as struggles; instead, they are seen as targets of patronising development or the repression deserved by traitorous subjects. What is more, the technologies and infrastructure for this development and/ or repression in China and India are linked to a global network of profitable corporate interests that work along supra and infrastatal pathways, while simultaneously abetting the denial of rights in order to marginalise minority populations in the name of Western politicking.

\section{Highlighting Commonalities}

In both the Indian and the Chinese cases, the uninhibited repression of Muslim-majority regions is aided by the fact that the international community is loath to take any substantive action due to their economic ties with these countries (Ma and Loanes 2019; SupChina 2019). Several Muslim countries refuse to speak up against India and China-for instance, Modi received state honours in the Middle East in August 2019 even as the constitutional coup was under way in Kashmir (Dorsey 2019), and Chinese Belt and Road Initiative investments are having a similar silencing effect on Muslim states. At the same time, statements by the United States are seen as hypocritical given the US's own record of human rights abuses that has only worsened under Donald Trump. The global Islamophobia unleashed in the wake of the War on Terror assists in the collective portrayal of Muslims in India as a threat.

In August 2016, the question 'Should India apply the "Chinese model for Xinjiang" in Kashmir?' on a popular web discussion forum received a variety of responses, revealing two common threads (Quora 2016). The first was that doing so was not possible because China was communist authoritarian and India democratic; the second was that Kashmir's autonomous status was guaranteed by Article 370 of the Indian Constitution. Commencing in July 2016, Kashmir was rocked by a massive anti-India uprising in which mass blindings were carried out using pellet guns. By 2020, Article 370 had been revoked, and there is an accelerated set of legal and policy moves to bring about demographic, environmental, and infrastructural changes in the region. It is conceivable that where Xinjiang leads, Kashmir may follow.

In 2019, The New York Times leaked pages of internal documents of the Chinese Communist Party (CCP)-which the journalists described 
as 'chillingly bureaucratic'-including handbooks with questions and model answers prescribed in order to instruct Uyghur students about their families taken away to camps ( $\mathrm{Ma}$ 2019). Furthermore, video surveillance firmslike Hikvision from China, a 'national AI champion' according to the CCP, and 'either owned or controlled by the Chinese military' according to the US Department of Defense (Dalmia 2020)-have gained increasing prominence in India, including through Indian government contracts under the Make in India initiative. As others have described, there are evident global linkages in the circulation and export of technologies that enable digital authoritarianism in which China's role is ever expanding (Feldstein 2019; Roche 2019).

Even though the relationship between China and India is marred by strategic rivalry over border issues, which periodically translates into clashes and loss of life, the economic ties between the two countries and the resonances between Xi's and Modi's projects to dominate Xinjiang and Kashmir overshadow these confrontations. The ethnonationalist struggles of the Muslim populations in Kashmir and Xinjiang have a long and complex history; indeed, there is even a small minority of Uyghurs who settled in Kashmir as transHimalayan migrants between the 1930s and the 1950s, as Communist China took shape. Kashmir today is not the same as Xinjiang, but many developments over the past year indicate that it might become more and more similar. The people in both these regions have to contend with a political rule that allows them limited rights or ability to dissent and is marked by deprivation of liberties and lack of accountability. Yet, in spite of sharing a historical border, the same religion, and fairly similar challenges, these groups are, if not unaware, at least fairly indifferent to each other's struggles. However, for those of usscholars, policymakers, and activists-who are able to witness the nature of the unfolding political dynamic in the two rising powers of China and India, it is important to highlight the commonalities in terms of strategies, speech acts, and circulations of technology that facilitate such projects. Further and more broadly, as I have argued here, we need to challenge the instrumentalisation of the moral wound of colonialism that translates into a postcolonial error, whereby non-Western countries are able to secure legitimacy and justification for their own exercise of colonial power. 
This text is taken from Made in China Journal: Volume 5, Issue 2, 2020 , edited by Ivan Franceschini and Nicholas Loubere, published 2020 by ANU Press, The Australian National University, Canberra, Australia.

doi.org/10.22459/MIC.05.02.2020.05 